DOI https://doi.org/10.30525/978-9934-588-86-0.19

\title{
LEGAL REGULATION OF SEAPORT ACTIVITY: PRINCIPAL PROBLEMS AND PROPOSITIONS FOR SOLUTIONS
}

\author{
Balobanov O. O., Fedchun N. O., Dopilka V. O.
}

\section{INTRODUCTION}

The main aim of the port reform is to change the post-soviet public port management system - combination of administrative (safety) functions and commercial activities (handling, storage, towage) within the unified state enterprise.

The international practice defines such a model of management as a national (public) service port.

During the soviet period, the ports concerned to be natural monopoly, so the port dues rates and handling rates, other services were defined by the state.

The process of the port reformation officially started with the Law of Ukraine "On seaports of Ukraine", so administrative and commercial activities in ports were separated. Mentioned process provided the opportunity for enterprises of various forms of ownership to carry out the main economic functions in port on competitive basis.

\section{SPECIAL RULES OF INTERNATIONAL PORT/HARBOR LAW}

General international rules. Although the law of ports and harbors, therefore, is a part of the law of the land, there are also essential provisions for the legal position of the ports before all three international agreements:

a) The Convention on Facilitation of International Maritime Traffic of 1965 and Annexes A and B as well as Resolutions adopted by the Conference of INCO (now IMO) as Annex $\mathrm{C}$ and of the terms to the Final Act of this Convention. The Convention was adopted by the IMCO member states on 9 April 1965 in London ${ }^{1}$. It concerns arrival and departure of persons, Public Health Measures and supplementary provisions.

b) The Procedure for the Control of Ships by Port States was adopted by IMO in 1975. The most essential rule of this agreement is art.VI para 1b) stating an obligation for state parties to notify representatives of the flag state of any information received about a substandard ship or of any intervention by executing control on such a ship.

\footnotetext{
${ }^{1}$ Douglas, R. P. A. An outline of the Law Relating to Harbors in Great Britain Managed under Statutory Powers, Second Edition, London, 1987.
} 
c) The ILO Umbrella Convention 147 "Merchant Shipping (Minimum Standards) Convention" of 1976 states that in taking action to rectify any condition on board which is clearly hazardous to safety of health, a port state must notify the nearest representative of the flag state and must if possible have such a representative present when the action is taken.

On the other hand, the IMO Convention clearly recognizes the state's sovereignty over its ports stating that the regulations of this convention should be regarded as complementary to its national measures. These measures as such are moreover mainly intended to assist the flag state in securing compliance with the convention provisions.

Particular international rules. In some parts of the world, some particular international rules have been created covering the harbor law of a certain community of states. Such a system characteristic e.g. for the Arab States on the Arab Peninsular and for the European States in the Western parts of Europe.

For Saudi Arabia as well as for the Arab States of the Gulf cooperation Council (GCC States) the rules for the state control of port life are a part of the "Rules and Regulations" of the Cooperation Council for the Arab States of the Gulf, Parts 1-3, of March 1985:

a) Part 1 - Regulations for Vessels in Port.

b) Part 2 - Regulations for Port Operations.

c) Part 3 - Regulations for Port Safety.

For all Western European countries as the member states of the European Economic Community a port state control has been fixed on the legal basis of the regional European Conference on Maritime safety of December 1980 by the "Memorandum of Understanding on Port State Control" of 1982/84 underlining the need to increase maritime safety and the protection of the marine environment as well as the importance of improving living and working conditions on board ships ${ }^{2}$.

Understanding in the form of the Memorandum has been reached on the following subjects:

a) Section 1 - Commitments to give practical effect to the provisions of this Memorandum and its Annexes.

b) Section 2 - Relevant instruments for the purposes of the Memorandum are:

- The International Convention on Load Lines of 1966.

- The International Convention for the Safety of Life at Sea of 1974.

- The Protocol of 1978 relating to the International Convention for the Safety of Life at Sea of 1974.

${ }^{2}$ BalobanovO. O. , Munari F., Succi D., Reynaud J. (2001) Ocherki po morskomu pravy [Essays on maritime law]. Odessa, 147-150. 
- The International Convention for the Prevention of Pollution from Ships of 1973 as modified by the Protocol of 1978 relating thereto.

- The International Convention on Standards of Training, Certification and Watchkeeping for Seafarers of 1978.

- The Convention on the International Regulations for Preventing Collisions at Sea of 1972.

- The Merchant Shipping (Minimum Standards) Convention of 1976 (ILO 147).

c) Section 3 - Inspection Procedures, Rectification and Detention.

d) Section 4 - Provision of Information.

e) Section 5 - Operational Violations.

f) Section 6 - Organization.

g) Section 7 - Amendments.

h) Section 8 - Supplementary rules, especially this Memorandum being without prejudice to rights and obligations under any international agreement.

The four Annexes comprise guidelines for surveyors, telex forms, and report on inspections and information system on inspections.

\section{Selected legal problems of tugs and towage.}

a) The towage contract.

The towing of ships into, within or out of the harbor is one of the most essential works to be done in the port area. Each agreement to tow and to be towed is a contract. They may be oral or written. Any vessel strong enough to pull another through the water may perform it, but towage is primarily the function of tugs, tracks of towage concern them most.

Decides towing, pushing, pulling and moving another water-born object, tugs now carry goods, men and supplies as a part of their contractual duties. In addition, some tugs are regularly engaged in laying-off anchors to hold oilrigs in place or in assisting specialist ships to place pipes on the seabed. The complexity and attention required for the performances of an ordinary harbor towage and that of towing a disabled ship across the Pacific will vary, but not the standard of care given to the performance itself.

Salvage rights are not based on the contract. They are matters of the public policy, tug owners and tug crews are as entitled as any other persons to claim them. The right of a tug to a reward in respect to a vessel it is towing under a pre-existing contract depends on whether a change of circumstances developed during the performance of the contract as to render its performance different from that which was contemplated by the parties when the contract was entered into force. The tug owner will be put to strict proof of any salvage claim ${ }^{3}$.

${ }^{3}$ Balobanov A. O. (2004) Pravovoe regulirovanie buksirovaniya. Problemu dogovorov po zakonodatelstvy Ukrainu i zarybejnomy zakonodatelstvy [Legal regulation of towage activity. Problems of contracts of Ukrainian and foreign legislation]. Transport - 2004, 150-151. 
Of especially great importance to tug owners are exemption clauses in the contract. Clauses of indemnity are regarded as equivalent for this purpose, and no distinction is drawn between then. Contracts of towage abound in both. Their effectiveness in general International Customary Law depends on their reasonableness and before all, whether they have been agreed by the contracting parties. No one likes exemption clauses except the ship, but the cargo owner can recover the whole damage from the carrying ship regardless of degree of fault in respect of that ship subject to the term of carriage.

Such a liability may be limited in certain cases according to national as well to International Law. The British Merchant Shipping Act of 1894 (as amended) is in so far remarkable as it tries to combine these two legal possibilities. Because in Section 503 of the Act it is ruled as follows partly:

a) where any loss of life or personal injury is caused to any person being carried on the ship,

b) where any damage or loss of life is caused to any goods, merchandise or other things whatsoever on board the ship,

c) where any loss of life or personal injury is caused to any person not carried on the ship through the act or omission of any person (whether on board the ship or not) in the navigation or management of the ship or in the loading, carriage or discharge of its cargo or in the embarkation, carriage or disembarkation of its passengers, or through any act or omission of any person on board of the ship,

d) where any loss or damage is caused to any property by the act or omission of the aforesaid persons, be liable to damages beyond the following amounts:

- in respect of loss of life or personal injury an amount not exceeding fifteen pounds for each ton of this ship's tonnage,

- in respect of loss or damage of property an amount not exceeding eight pounds for each ton of this ship's tonnage.

It must be noticed, that although the tug's owner's limit is rather low due to the tugs small registered tonnage, the combined tonnages of tug and tow may be considerably higher. Findings of fact relating to the faults of tug, tow and/or the third vessel are crucial importance. The fault may be attached to one or more of the vessels involved and in varying degrees. Where loss need to be divided and fault apportioned, only one of the vessels is liable. If the tug is that vessel, the ability of the owners to limit their liability to the tonnage of the tug alone is undisputed, since the negligent navigation of the tug cannot be visited upon the innocent tow. The same is due to the tow vice versa.

This national limitation of liability is again a result of four International agreements on this subject: 
a) The International Convention for the Unification of Certain Rules Relating to the Limitation of the Liability of Owners of Seagoing Ships, Brussels, 1924.

b) The International Convention Relating to the Limitation of the Liability of Owners of Seagoing Ships, Brussels, 1957.

c) Protocol amending the International Convention Relating to the Limitation of the Liability of Owners of Seagoing Ships (Brussels, 1957) of 1979.

d) Convention on Limitation of Liability for Maritime Claims, London, 1976.

Most of the legal details of these conventions are a part of the already mentioned British Merchant Shipping Act of 1894 (as amemded).

\section{GENERAL PROBLEMS OF SEAPORT REFORM IN UKRAINE: LEGAL ASPECTS}

Analyzing modern trends, it can be confirmed, that the Ukrainian transport policy is transforming towards public-private partnership. In Ukraine such activity has corresponding legal base, presented by the Constitution of Ukraine, the Civil Code of Ukraine, the Economic Code of Ukraine, the Law of Ukraine "On concessions" est.10/3/2019. Mentioned law defines the definition and legal grounds of state and communal property concession relations in order to increase efficiency of its exploitation and provision of needs for goods (works and services) of citizens of Ukraine. Another Law of Ukraine "On state-private partnership" N 2404-VI est.7/1/2010, regulates the relations within cooperation between private subjects and the state on the realization of investment projects providing private investments in the development of the economy public sector.

The administrative port authority is presented by the State enterprise Administration of seaports of Ukraine via ports affiliates. Nevertheless, nowadays, the Ukrainian port management system cannot be characterized, in its pure form, as a certain World management model, such as the Landlord port, the Tool port and the Service port.

Considering inclusion of the Ukrainian ports in the World logistic systems, such uncertainty creates various difficulties, including the sphere of legal regulation of port activity. From the other side, the formation of the legal basis for the reformation of port activity is the key requirement for the reformation itself $^{4}$.

${ }^{4}$ Balobanov A. O. (2010) Organizacionno-pravovye aspekty syurvejerskoj deyatelnosti [Organizational-legislative aspects of surveying activity]. Odessa : Feniks. 95-96. 
The legislation on the seaports is based on the Constitution of Ukraine, the Merchant Shipping Code of Ukraine, the Civil Code of Ukraine, the Budget Code of Ukraine, the Tax Code of Ukraine, the Land Code of Ukraine, the Water Code of Ukraine and consists of the Laws of Ukraine "On seaports of Ukraine", "On transport", "On natural monopoly" and other legal acts.

The general principals, the main directions and ways of improvement of seaports and port industry in general are determined by the Strategy development of seaports of Ukraine till 2038, approved by the Cabinet of Ministers of Ukraine on July 11, 2013 № 548-p.

The aim of the analyzed Strategy development of seaports of Ukraine till 2038 is:

- to provide comprehensive development and increase the competitiveness of the port industry;

- to ensure proper maintenance, effective management and use of strategic facilities of port infrastructure;

- the involvement of long-term private investment for the development of port infrastructure facilities;

- to create conditions for economic activities in the seaport, equal access to services provided by the seaport;

- to create clusters network;

- to provide navigation safety, life and health safety of people and economic activity that is carried out in the seaport, safe operation of port infrastructure facilities;

- to provide supervision (control) safety in maritime transport;

- to provide material and technical and technological development of the port industry and staff training;

- to prevent environmental pollution, enforcing the use and protection of water facilities within the territory and water area of the seaport;

- environmental safety in accordance with international standards.

The main objectives of the Strategy development of seaports of Ukraine till 2038 are:

- to improve the competitiveness of the port industry by increasing the efficiency, quality and speed of cargo handling, modernization and development of port infrastructure facilities of public use, particularly, road and rail access roads, ensuring the effective state regulation of specialized services provided by subjects of natural monopolies in the seaport, and services, payment for which is included in harbor dues, improvement of office administration, simplification of licensing procedures, reducing the time of cargo handling, creating conditions for fair competition among domestic seaports, providing equal and 
competitive conditions for economic activities and receiving services in the seaport, coordination on capacity and increasing reloading facilities in ports;

- provision of technological development of the port industry and training of port industry specialists through introduction of modern technologies for cargo handling, improvement of training facilities for training port industry specialists;

- creation of clusters network by establishing a list of seaports and types of clusters, expanding the list of services provided by seaports, attraction private investment for the development of seaports, transmission of port industry companies and parts of port infrastructure facilities, particularly, in the concession;

- active participation in international organizations in order to create conditions for cross-border cargo traffic;

- compliance the standards of seaports with the European ones;

- interaction with the seaports of the Black Sea basin countries (development and implementation of programs to attract cargo flows, etc.);

- creating favorable conditions to attract private investment for the development of port infrastructure facilities;

- to provide state guarantees and investor rights protection;

- to ensure the creation of sufficient depth on the approaching roads and water area of the seaports to service large vessels at the berth;

- modernization and upgrade of port and auxiliary fleet;

- to ensure effective functioning of the monitoring of surface conditions in the territorial waters of Ukraine, optimizing the regulation of maritime traffic, effective and timely search and rescue at sea;

- provision of vessel traffic management system;

- to ensure the development of port community information system, process technology information at seaports;

- to improve procedures of cargo clearance, vehicles and passenger transportation;

- to draw up international agreements regarding the search and rescue at sea;

- purchase and upgrade of emergency facilities;

- to ensure effective functioning and development of technical and information support of navigation safety;

- improvement of human resources, renewal and improvement of educational and technical resources for staff training of port industry;

- development of training programs for workers of seaports to maintain new technological complexes;

- to support educational institution of training port industry specialists;

- to improve the protection of labor; 
- to provide proper sanitary conditions in the seaports;

- to ensure the use of social infrastructure of port industry for the intended purpose;

- implementation of the EU standards on dangerous cargoes;

- compliance of environmental safety standards of seaports with international ones.

In the aim to achieve mentioned goals the following priority directions have been formed:

- direction 1. Balanced development and effective exploitation of port capacity based on innovative grounds;

- direction 2. Providing the competitive logistics and improvement of seaport services;

- direction 3. Optimization of the management system in the seaport field.

Despite the fact that more and more attention is paid on concession and privatization, today the leasing of public property stays still as a real operational mechanism on investments attraction. The main disadvantage of leasing for an investor considers to be an established Ukrainian practice of tenant's incompetency on conduction inseparable improvements and the lack of the right on compensation of invested in such improvements.

Such concept requires changes; forasmuch the investment platform might be built on the basis of public property. For starting of such platform the reconstruction and write-off of worn-out public property have to be held, and the compensation of investments should be guaranteed for the investor. First of all, such steps will give the opportunity for state, remaining the public property owner, to attract the investments in the maritime field development on the basis of existing well-developed, clear and regular legal mechanism of leasing in parallel with concession and privatization processes ${ }^{5}$.

Today, the opportunity to transfer the integral complex of port property to a concession is defined by the legislation of Ukraine.

Attracting private investment in privatization process might reinforce the state modernization policy and increase competitiveness of maritime transport as one of the directions of the Strategy development of seaports of Ukraine till 2038.

However, decision-making concerning one or another form of publicprivate partnership should be based on complex research of investment attractiveness of a certain seaport and its competitive state on market. That will

5 Balobanov A. O. (2007) Pravovoe regulirovanie portov, perevozok i agentskih kompanii [The legal regulation of ports, forwarding and agency companies Part I.]. Odessa, Publishing office of ONMU, 71-78. 
show the potentiality of a port and perspective directions of its development, as soon as its weak sides and problem areas. On the basis of conducted research a certain effective direction of investment, which meets the goals of the state and private partnership, can be selected.

\section{ENSURING THE ECONOMIC SECURITY OF IN SEAPORTS}

Maritime safety is an activity at sea that excludes harm to life, human health, the marine environment and property and is provided by economic, technical and legal means, including state supervision of vessels. Technical and legal norms determine the order of use of vehicles, including for the purpose of economic safety.

Seaports are an integral part of shipping. Increasing the volume of world trade, maritime commercial traffic contributes to the growth of ports and requires improvement of their activities. In the inspection of ships, the Law "On Seaports" defines a clear interaction of the port authorities with the bodies that carry out customs and other types of control and supervision in the port in order to ensure economic security.

The purpose of the study is the legal regulation of goods (objects) moving across the customs border and its importance in preventing damage to the economic security of navigation.

International conventions establish rules for ensuring the safety of navigation; in their implementation the central place is occupied by control of the port state. The form of control is inspection of vessels. Inspection of ships in ports is carried out on the subject compliance of the vessel's condition with the requirements of international conventions on maritime safety.

The 1982 United Nations Convention on the Law of the Sea provides that the flag State of a vessel shall ensure that its compliance with the safety of navigation is monitored. According to Art. 85 of the Merchant Shipping Code of Ukraine, the state supervision of navigation in port is carried out by the captain of port who heads inspection of the state port supervision.

The inspection, upon departure of the vessel, complies with the requirements for the safety of navigation. However, shipping under "convenient flags", a rare call at the port of registration of the vessel reduces the possibility of its control by such a state. Therefore, such control over the substance is possible in the port of call of the vessel. The procedure for registration of the vessel's arrival at the seaport, granting permission for the vessel to enter the sea and registration of the vessel's exit from the sea from the seaport is determined by the Order of the Ministry of Infrastructure of Ukraine № 430 dated 27.06.2013. 
With the entry of the vessel into the territorial waters, a customs inspection is carried out. A customs representative may inspect the vessel and accompany it to the berth. Customs clearance may be in the parking lots or berths of the port on internal or external raids. After arrival of the vessel in the territorial waters of the state, it is under customs control. Exceptions are foreign ships of the Navy and border troops, as well as military equipment that goes on its own. Some officials who cross the border in the performance of their duties are not subject to customs control. The coastal States shall open ports for the unloading or loading or disembarkation of passengers only after customs control. All goods moving across the customs border are subject to customs inspection ${ }^{6}$.

The subject of control can be any goods, they include currency values. During the customs inspection, special attention should be paid to items that have been withdrawn from civil circulation, as well as the detection of items of criminal smuggling. Such items include cultural property, poisonous and potent, explosives, radioactive materials, weapons or ammunition, parts of firearms, special technical means of covert information (Article 201 of the Criminal Code of Ukraine), as well as drugs, psychotropic substances, their analogues or precursors or counterfeit medicines (Article 305 of the Criminal Code of Ukraine).

A special declaration of the presence on board of the ship of the first aid kit with drugs containing narcotic drugs, psychotropic substances and precursors is required.

The law establishes liability for illegal transportation of excisable goods (Article 204 of the Criminal Code of Ukraine). A separate review of tobacco and alcohol products takes place, so that their number does not exceed the need for crew members while the ship is in port. Currency and currency values are subject to customs inspection for falsification.

The law penalizes the movement for sale of counterfeit currency and currency values for sale (Article 199 of the Criminal Code of Ukraine).

Foodstuffs, water in the quantity necessary for the provision of the vessel, as well as items of material and technical supply are subject to inspection. The ship's stock declaration must contain information on the foodstuffs available on the ship and intended for its supply, as well as fuel and lubricating oils.

The objects that arrive for repair or delivery to the consignee are subject to customs control and registration of vessels sailing abroad. The customs border of Ukraine for the purpose of repair, as well as equipment and materials

${ }^{6}$ Dodin, E. V. (2001) Tamojennue operacui na morskom transporte. Mejdunarodnoe morskoe pravo i Chernomorskii region [Customs operations on maritime transport. International Law of the Sea and the Black Sea Region]. Odessa. (in Russian). 
intended for their repair in the customs territory of Ukraine, in accordance with the provisions of the Customs Code of Ukraine, may be temporarily imported / exported (Chapter 38 of the Customs Code of Ukraine) or processed in the customs territory Of Ukraine (Chapter 23 of the Customs Code of Ukraine). A certain amount of funds used for ship repair is subject to customs control during ship repair.

When revealing the facts of non-declaration of goods, commercial vehicles moving across the customs border, there is an administrative liability (Article 472 of the Customs Code of Ukraine, Articles 285-289 of the Code of Administrative Offenses of Ukraine). For non-declaration of goods, commercial vehicles illegally moving across the customs border, entails the imposition of a fine and confiscation of these goods and vehicles.

A special role is played by the seaport in relation to cargo arriving for shipment by sea or other water transport, or for delivery to the consignee, as well as transit cargo that is not moved by the direct option "vehicle - ship", such cargo is stored in the port and to fulfill other obligations under the contract of carriage. The operating conditions of the port allow to ensure a single logistics process of cargo handling by different modes of transport in the sea terminal. A special procedure is established for dangerous goods ${ }^{7}$.

Special rules for the transport of dangerous goods, provided for in Article 13 of the UN Convention on the Carriage of Goods by Sea (Hamburg, 1978). From the point of view of maritime safety, the transportation of grain, oil products and coal deserves special attention. The legislation of Ukraine provides for a set of administrative actions granted to the subject of foreign economic activity permission for a certain quota (quantitative or other restrictions). Administrative actions may include the movement of the above cargo, its processing. Customs clearance includes inspections, surveys, inspections, examinations. The Civil Code of Ukraine provides, in relation to the duty of the custodian, to indicate the quantity and quality of the goods, the conditions of its storage, the obligation to return it.

When transporting cargo, the port is obliged to ensure its safety, and the chemical and physical qualities of the cargo must be recorded when they are loaded on the ship. The master of the vessel is obliged to ensure the preparation of all premises of the vessel, in which the cargo is transported, for the safety of the transported items, the correctness of their placement ${ }^{8}$.

${ }^{7}$ Moroz, I. (2008) Osobennosti polucheniya kvot v zernovoy promyshlennosti [Features of obtaining quotas in the grain industry]. Agroprofi, 14. (in Russian)

8 Balobanov A. O. (2007) Pravovoe regulirovanie portov, perevozok i agentskih kompanii [The legal regulation of ports, forwarding and agency companies Part 2.]. Odessa, Publishing office of ONMU, 34-36. 
Before accepting the cargo, the captain considers and approves the cargo plan, which provides for the conditions of storage of cargo, safety of the vessel and people. The master of the port shall inspect in accordance with the plan of cargo placed on the vessel.

\section{CONCLUSIONS}

In result of above research the following propositions for solutions may be presented:

1. To reform the port authorities, first of all State enterprise Administration of seaports of Ukraine, so that the management system and strategy development might be formed with the involvement of port council, local governments, scientific and applied researches. The first and the easiest step can occur in granting the status of legal entity to the port administration with further assignation of all functions and duties provided by law. Scilicet, in fact - the real decentralization in the sphere of maritime transport.

2. To re-establish the institute of nodal agreements between different kinds of transport that should become a legal ensuring apparatus of logistic centers in ports.

3. To define clearly the criteria and definitions concerning the status of port operator, port terminal, and consumer of port service, scilicet their legal personality in port activity.

4. To concretize the model of management, development of infrastructure and investment from public and private sources considering the peculiarities of each port.

5. To develop the staff professionalism, especially, in terms of maritime transport component (retraining, advanced training, etc.).

\section{SUMMARY}

Analyzing modern trends, it can be confirmed, that the Ukrainian transport policy is transforming towards public-private partnership. Considering inclusion of the Ukrainian ports in the World logistic systems, such uncertainty creates various difficulties, including the sphere of legal regulation of port activity. From the other side, the formation of the legal basis for the reformation of port activity is the key requirement for the reformation itself.

Decision-making concerning one or another form of public-private partnership should be based on a complex research of investment attractiveness of a certain seaport and its competitive state on market. That will show the potentiality of a port and perspective directions of its development, as well as its weak sides and problem areas. On the basis of conducted research a certain effective direction of investment, which meets the goals of the state and private partnership, can be selected. 


\section{REFERENCES}

1. Balobanov, A. O. (2004) Pravovoe regulirovanie buksirovaniya. Problemu dogovorov po zakonodatelstvy Ukrainu i zarybejnomy zakonodatelstvy [Legal regulation of towage activity. Problems of contracts of Ukrainian and foreign legislation]. Transport - 2004, 150-151. (in Russian)

2. Balobanov, A. O. (2007) Pravovoe regulirovanie portov, perevozok i agentskih kompanii [The legal regulation of ports, forwarding and agency companies Part I.]. Odessa, Publishing office of ONMU. (in Russian)

3. Balobanov, A. O. (2007) Pravovoe regulirovanie portov, perevozok i agentskih kompanii [The legal regulation of ports, forwarding and agency companies Part 2.]. Odessa, Publishing office of ONMU. (in Russian)

4. Balobanov, A. O. (2010) Organizacionno-pravovye aspekty syurvejerskoj deyatelnosti [Organizational-legislative aspects of surveying activity]. Odessa: Feniks. (in Russian)

5. Balobanov, A. O. (2011) Organizaciini ta pravovi osnovu upravlinnya portamu (Zakon Ukrainu "Pro mors'ki portu") [Organizational and legal bases of port management (Law of Ukraine "On maritime ports of Ukraine")]. Odessa: Publishing office of ONMU. (in Ukrainian).

6. Dodin, E. V. (2001) Tamojennue operacui na morskom transporte. Mejdunarodnoe morskoe pravo i Chernomorskii region [Customs operations on maritime transport. International Law of the Sea and the Black Sea Region]. Odessa. (in Russian).

7. Douglas, R. P.A. An outline of the Law Relating to Harbors in Great Britain Managed under Statutory Powers, Second Edition, London, 1987.

8. Gaskell, N. J. J., Debattista, C. A. and Swatton, R. J. Shipping Law, Eight Edition, London, 1987.

9. Moroz, I. (2008) Osobennosti polucheniya kvot v zernovoy promyshlennosti [Features of obtaining quotas in the grain industry]. Agroprofi, 14. (in Russian)

10. Singh, M. V. The International Maritime Law Conventions, Vol. 4, Maritime Law London, 1983.

\section{Information about the authors:}

Balobanov, O. O., $\mathrm{PhD}$, Professor, Head of the Department "Transport Law", Odessa National Maritime University 34, Mechnikov str., Odessa, 65029, Ukraine ORCID ID: orcid.org/0000-0002-2586-015X 
Fedchun, N. O., $\mathrm{PhD}$, Associate Professor at the Department of Criminology and Criminal-Executive Law, National University "Odessa Law Academy" 25, Fontanskaya way str., Odessa, 65009, Ukraine ORCID ID: orcid.org/0000-0002-9634-5411

Dopilka, V. O., $\mathrm{PhD}$, Associate Professor at the Department "Transport Law",

Odessa National Maritime University 34, Mechnikov Str, Odessa, 65029, Ukraine ORCID ID: orcid.org/0000-0003-2159-6387 